\title{
BUL: a novel lectin from Bauhinia ungulataL. seeds with fungistatic and antiproliferative activities
}

\author{
André Silva ${ }^{1 *}$, Talita Leite ${ }^{1}$, Edson Teixeira ${ }^{1}$, Luiz Ponte ${ }^{2}$, Luciano Pinto ${ }^{3}$ \\ From 5th Congress of the Brazilian Biotechnology Society (SBBIOTEC) \\ Florianópolis, Brazil. 10-14 November 2013
}

\begin{abstract}
A new galactose-binding lectin, termed BUL, has been purified from seeds of Bauhinia ungulata (Caesalpinoideae) by precipitation with solid ammonium sulfate followed by agarose-lactose affinity chromatography. B. ungulata lectin strongly agglutinated rabbit erythrocytes, both native and treated with proteolytic enzymes, and was inhibited by $\mathrm{D}$-galactose and D-galactosederived sugars, especially $\mathrm{N}$-acetyl-D-galactosamine. BUL was shown to be a stable glycoprotein, maintaining its hemagglutinating activity after incubation at wide ranges of temperature and $\mathrm{pH}$, but not after incubation with EDTA. By SDS-PAGE analysis under reduced conditions, purified BUL showed an electrophoretic profile consisting of a single band with apparent molecular mass of $30 \mathrm{kDa}$. BUL showed intrinsic fluorescence typical of folded globular proteins, and circular dichroism spectra of lectin in the native state showed a predominance of $\beta$-sheet secondary structure. The N-terminal amino acid sequence of 19 residues showed a high sequential similarity to other galactose-specific lectins from the Bauhinia genus. In addition, BUL showed antifungal activity against phytopathogenic species and showed in vitro antiproliferative activity against the HT29 cell line of human colon adenocarcinoma in a dosedependent manner.
\end{abstract}

\section{Authors' details}

${ }^{1}$ Universidade Federal do Ceará, Fortaleza, Brazil. ${ }^{2}$ Universidade Estadual do Vale do Acaraú, Sobral, Brazil. ${ }^{3}$ Universidade Federal de Pelotas, Capão do Leão, Brazil.
Published: 1 October 2014

doi:10.1186/1753-6561-8-S4-P87

Cite this article as: Silva et al:: BUL: a novel lectin from Bauhinia ungulataL. seeds with fungistatic and antiproliferative activities. BMC Proceedings 2014 8(Suppl 4):P87.

'Universidade Federal do Ceará, Fortaleza, Brazil

Full list of author information is available at the end of the article

Submit your next manuscript to BioMed Central and take full advantage of:

- Convenient online submission

- Thorough peer review

- No space constraints or color figure charges

- Immediate publication on acceptance

- Inclusion in PubMed, CAS, Scopus and Google Scholar

- Research which is freely available for redistribution
C Biomed Central
C Biomed Central

(c) 2014 Silva et al.; licensee BioMed Central Ltd. This is an Open Access article distributed under the terms of the Creative Commons Attribution License (http://creativecommons.org/licenses/by/4.0), which permits unrestricted use, distribution, and reproduction in any medium, provided the original work is properly cited. The Creative Commons Public Domain Dedication waiver (http://creativecommons.org/publicdomain/zero/1.0/) applies to the data made available in this article, unless otherwise stated. 